\title{
ACCOMMODATION OF WESTERN LEGISLATION FOR PLURALITY OF BELIEFS IN FAMILY LAW
}

\author{
Zoila Combalía \\ Faculty of Law, University of Zaragoza, Spain \\ email: combalia@unizar.es
}

COMBALÍA, Zoila. Accommodation of Western Legislation for Plurality of Beliefs in Family Law. International and Comparative Law Review, 2011, Vol. 11. No. 1, pp. 77-85. DOI: 10.1515/iclr-2016-0096.

\begin{abstract}
In the last several years, the European societies, that in their majority were fairly uniform as far as race, culture or religion, have been converted into intercultural places where many different visions of the world live together. Together with a factor of exogenous plurality, produced by the increase in immigration, an internal desegregation should also be highlighted in our own societies. In this new environment of diversity, it is without a doubt, difficult for the Law to accommodate all the different ethical, religious or cultural demands of the people. In my paper I study the means of accommodation rooted in our legal tradition such as: the conscientious objection, the agreements of the State with religious groups, mediation and arbitration as a way of accommodation of plurality in the field of Family Law, etc. I conclude by stressing the fact that allowing space for diversity does not mean giving up our own values. Quite the opposite, accommodation comes from our own values: that is, from the respect for freedom and non-discrimination, founded on the dignity of the person.
\end{abstract}

Keywords: Plurality, multiculturalism, religious freedom, conscientious objection, human rights, Law and Religion.

\section{Conscientious objection in a pluralistic society.}

In the last few years, the Western European societies, that in their majority were quite uniform as far as race, culture or religion are concerned, have been converted into intercultural places where many different visions of the world live together.

Besides a factor of exogenous plurality, produced by an increase in immigration, an internal desegregation should also be highlighted in our own societies. The result is that we find living, under the same jurisdiction, people with very different convictions such as: agnostics, Catholics following the teachings of the 
Church, Muslims of distinct tendencies, protestants, Jehovah witnesses, etc. This is a rather new situation in our countries ${ }^{1}$.

In this current environment of diversity, it is difficult for the Law to accommodate all the different ethical, religious or cultural demands of the people, especially due to the lack of flexibility in the Civil Law or Continental-Law countries (to a lesser extent in the Common-Law countries, which enjoy a rather flexible system).

Thus, we find ourselves with a double conflict:

a) On the one hand, the conflicts of individual convictions colliding with the legal system. This is what happens with conscientious objection.

In just a few years, we have gone from the almost-exclusive prominence of the objection to military service, to the proliferation of objections in different areas: in the health arena (objection to abortion, artificial reproduction...), objection to medical treatments or blood transfusions, objections in the labor field (for example, to work on certain holidays), etc. ${ }^{2}$

Recently, in Spain, two new types of objections have been proposed: the objection of judges to the celebration of marriage between people of the same sex and the objection of some parents to their children receiving the new subject: "civic education", due to it contents.

b) On the other hand, together with the conflict of the people who reject the legislation as contrary to their own value system, due to immigration we find ourselves with conflicts arisen from the penetration in the Law of foreign cultural-religious elements, with the consequent "perplexity" of the Law.

This is what happens, for example, with some Islamic matrimonial institutions such as polygamy, unfamiliar to our legal tradition and values. The Western European legal systems do not recognize polygamous marriage because of domestic public policy. However, despite the direct rejection, the Law is forced to give some indirect effects to polygamy ${ }^{3}$. This happens, for example, when the several wives of a polygamist immigrant, legally married to him in their country of origin, claim a widow's pension in their host country. In these cases, the Spanish courts have agreed to divide the pension among the wives, assigning equal parts to each of them (regardless of the amount of time spent living with

1 Certainly Spain has an important historical tradition of coexistence between cultures, but this tradition ended with the expulsion of Muslims and Jews in the XV century. Since then, we have had a quite uniform society.

2 For an interesting reflection about this proliferation and its reasons see R. NAVARROVALLS and J. MARTÍNEZ-TORRÓN, Las objeciones de conciencia en el Derecho español y comparado, Ed. McGraw-Hill, Madrid 1997, pp. 1-8.

3 For penetration of Religious Law in State Law see Z. Combalía, Recepción del Derecho islámico matrimonial en la jurisprudencia estadounidense, Ed. Comares, Granada 2006, pp. $1-5$. 
the husband), therefore giving indirect recognition to polygamy ${ }^{4}$. Another example of indirect recognition is produced when the polygamist immigrant tries to regroup with his different wives ${ }^{5}$. He is only allowed to regroup with one of them, not necessarily the first one; he can regroup as spouse with the second, the third or the fourth wife and the choice is up to the husband. So, it is also an indirect recognition to polygamy.

Thus, as a consequence of the plurality of our new social horizon in Western Europe, we require to move towards a more flexible Law in order to accommodate the diversity.

Before referring to the possible tools of accommodation I shall briefly mention the theories contrary to accommodation.

\section{An alternative between "secular absolutism" and "mosaic societies" to accommodate the plurality of society.}

Opposed to the need of moving towards flexibility is the so-called "secular absolutism"'. In this approach, the myth of the neutrality of secular law and the privacy of convictions survive. According to this view, beliefs should remain in the private arena (the home, the conscience, the temple), because when they invade public life, they disturb social peace and cohabitation.

4 See, f.i., the judgment of the Tribunal Superior de Justicia de Galicia, 2 de abril de 2002. A commentary on it can be found in A.L. DE VAL TENA, Matrimonio poligámico y pensión de viudedad. Comentario a la STSJ de Galicia de 2 de abril de 2002, en "Aequalitas. Revista Jurídica de la Igualdad de Oportunidades entre Mujeres y Hombres", nn. 10-11, mayodiciembre 2002, pp. 68 y ss.

5 See C. ESPLUGUES MOTA, Inmigración y Derecho de extranjería (especial referencia a la reagrupación familiar), en A. RODRÍGUEZ BENOT (Dir.), "La multiculturalidad: especial referencia al Islam", Madrid 2002, pp. 89-142.

A Directive of the Council of the European Union states that "the right to family reunification should be exercised in proper compliance with the values and principles recognized by the Member States, in particular with respect to the rights of women and of children; such compliance justifies the possible taking of restrictive measures against applications for family reunification of polygamous households" (Council Directive 2003/86/EC of 22 September 2003 on the Right to Family Reunification, 3 October 2003, 2003/86/EC, available at: http://www.unhcr.org/refworld/docid/3f8bb4a10.html - accessed 29 October 2009). For the Spanish regulation on this issue see section 11 of the Ley Orgánica 4/2000, 11 de enero, sobre Derechos y Libertades de los Extranjeros en España y su Integración Social, en su redacción dada por la Ley Orgánica 8/2000, de 22 de diciembre, por la Ley Orgánica 11/2003, de 29 de septiembre y por la Ley Orgánica 14/2003, de 20 de noviembre.

6 This is the expression used by in the Report on review of arbitration process prepared by the former Ontario attorney general Marion Boyd because of the social debate caused by Islamic arbitration.

See the report in: http://www.attorneygeneral.jus.gov.on.ca/english/about/pubs/boyd/. 
A clear example of this consideration is the polemic French law that prohibits the Islamic headscarf or other religious signs in public schools ${ }^{7}$. The philosophy underlying is that religion should not be present in school. The notion of secularity that proposes turning religion into a "bubble religion", that is not present in (that does not contaminate) society, ties in with an ancient opinion that springs from the French Revolution in 1789 and that historically had its raison d'être in Europe, and was possibly even necessary. But, in the XXI century, if the secular State is not at the service of people's freedom to profess their religion; if, in the name of secularity, freedom is banned, then an abuse is being committed that in my opinion, cannot be justified and jeopardizes democracy and the progress on which it is frequently based. That is, what was a step forwards in the XIX century, is a step backwards in the XXI century.

Opposite to assimilationism we have the so-called "mosaic societies" in which different cultures coexist, without mixing with one another: that is to say that cultural ghettos are created made up of foreigners who do not know the language, who do not attend the same schools, who do not go to the same shops, and who do not establish relationships with people from their adoptive country.

The alternative to both extremes would be that of a single intercultural society: common, yet plural, with shared basic values, but one in which there is room for everyone. This intercultural-ness would suppose: a) on the one hand, the acceptance of certain common principles and values that would be defined by the dignity of the person and respect for human rights; ${ }^{8}$ ) but, on the other hand, along with the acceptance of certain common principles, respect for plurality.

I shall now refer to some tools rooted in our legal tradition that we can use to make the Law more flexible in order to accommodate plurality.

7 Law no 2004-228 of 15 March 2004, concerning, through the application of the principle of laïcité, the wearing of symbols or clothing demonstrating religious affiliation in state primary and secondary schools. About the affaire du foulard islamique and religious symbols, see: B. BASDEVANT-GAUDEMET, L'Islam en France, en "Forum Internazionale ed Europeo di Riserche sull'Immigrazione): Il trattamento giuridico delle minoranze islamiche in Europa e negli Stati Uniti” (en http://www.fieri.it); S. CAÑAMARES, Libertad religiosa, simbología y laicidad del Estado, Ed. Aranzadi, 2005, pp. 68 y ss.; D. LE TOURNEAU, Le laïcité à l'épreuve de l'Islam. Le cas du port du "foulard islamique' dans l'école publique en France, en "Revue Générale de Droit", 28, 1997, pp. 275-306; M.J. ROCA, La jurisprudencia y doctrina alemana e italiana sobre simbología religiosa en la escuela y los principios de tolerancia y laicidad. Crítica y propuestas para el Derecho español, en "Anuario de Derecho Eclesiástico del Estado", vol. XXIII, 2007 pp. 257-291.

8 From this standpoint, "cultural" practices such as genital mutilation would plainly be unacceptable. This is what is clearly stated in a law that came into effect in Spain a few years ago with the purpose of fostering the social integration of immigrants. Between several reforms it typifies genital mutilation as a separate crime on the basis that (I read the introduction of the Law) it is "a practice that must be fought against with all the force possible, without any possible justification on the basis of so-called religious or cultural grounds". 


\section{Means of accommodation rooted to our legal tradition.}

\subsection{From the "conscientious objection" to the legally protected "conscientious option".}

A way to avoid the conflicts between Law and convictions would be to convert the foreseeable conscientious objections in legally protected options when the ethical rejection of certain sectors of society is expected, as is the case of laws approved after an important social controversy. That is the case in Spain, for example, regarding same-sex marriage law ${ }^{9}$.

It would mean the inclusion of a conscientious clause in the controversial regulation. The advantage of this process is that it does not place the objector in opposition to the system, but within it.

Spain stated this, by constitutional imperative, for the objection to military service. On the other hand, almost all the Western European laws legalizing abortion include a conscientious clause for the health personnel ${ }^{10}$. In Spain, when the jury law was passed, there was an amendment (that eventually did not prosper) to include the conscientious objection within the excuses to act as jury ${ }^{11}$.

So, to convert conscientious objections into a legal option would be a way to accommodate plurality within the Law.

3.2. The agreements of the State with religious groups as a means of accommodation.

Another possible tool to accommodate the Law to the demands of conscience are the Agreements of the State with religious communities.

We have this system of Cooperation Agreements for example in Spain, Germany and Italy.

In Spain, bilateral instruments to regulate matters of common interest between Church and State have used since the eighteenth century, but exclusively to define the legal status of the Catholic Church. These were the Concordats, an ancient institution with a legal nature analogous to that of international treaties. The Concordat with the Catholic Church that is currently in effect in Spain dates from 1976-1979. One year later, in 1980, as a consequence of the Constitutional neutrality of the State, the Organic Law of Religious Freedom created a sort of

9 On conscientious objection to the celebration of same sex marriage in Spain see R. NAVARROVALLS, La objeción de conciencia a los matrimonios entre personas del mismo sexo, en "Revista General de Derecho Canónico y Derecho Eclesiástico del Estado”, n. 9, septiembre 2005, en www.iustel.com.

10 Recently a new legaslation on abortion has been enacted in Spain (Ley Orgánica 2/2010, de 3 de marzo, de salud sexual y reproductíva y de la interrupción voluntaria del embarazo). It provides specifically in section 19.2 the conscientious objection of the health staff.

11 See J. FERRER ORTIZ, La objeción de conciencia al jurado, en "Revista General de Derecho Canónico y Derecho Eclesiástico del Estado”, n. 2, mayo 2003, en www.iustel.com. 
replica of the Concordats and made it available to any religious community with deep roots in Spanish society ${ }^{12}$.

Which religious beliefs have been considered to have deep roots in Spain? In addition to The Catholic Church, Protestants, Jews and Muslims were, and in 1992 these three religions signed their respective cooperation agreements with the State ${ }^{13}$.

The Agreements are, without any doubt, an appropriate instrument to the accommodation of religious diversity. In this way, the Agreements recognize civil validity of marriage administered in accordance with the Canon law or with the Islamic, Jewish or Evangelical ceremony. They recognize the communities the possibility of teaching their religion in state schools when students ask for it; and if there are at least ten students in each class, the teacher is paid by the State. In the agreements with the Jews and Muslims, the public powers commit themselves to protecting, in terms of food products, the denomination halal (for the Muslims) and kosher (for the Jews). If the communities register these denominations in the Patent and Trademark Office, it is guaranteed that the products that carry the denomination will be produced in accordance with the respective religious laws. This order is not stipulated for Christians, who have no religious dietary laws. In matters of religious holidays, the Agreements establish, for example, (I copy the Agreement with the Jews although the other two Agreements are expressed in similar terms): "The weekly day of rest of the followers of the Communities belonging to the Federation of Jews Communities may, with the agreement of the parties, include Friday evening and Saturday, in lieu of the day provided by (...) the Workers' Statute as the general rule..." (art. 12). Although the adaptation submits to mediating an agreement between the parties, one should at least understand that there is a certain obligation for the employer to try, if possible, a reasonable adjustment.

In short, the Agreements are an appropriate instrument to efficiently resolve the conflicts that religious communities can provoke in the adaptation of their religious precepts to the general demands of legislation. Nonetheless we are not taking all the advantages that the Agreements are able to provide us.

In Spain, there was a lot of interest in signing the Agreements with Muslims, Jews and Protestants in 1992, coinciding with the 500-year anniversary of

12 Art. 7,1: "The State, taking account of the religious beliefs existing in Spanish society, shall establish, as appropriate, Cooperation Agreements or Conventions with the Churches, Faiths or Religious Communities enrolled in the Registry where warranted by their notorious influence in Spanish society, due to their domain or number of followers. Such Agreements shall, in any case, be subject to approval by an Act of Parliament".

13 Laws nn. 24, 25 and 26 of 10 November 1992 approving the Cooperation Agreement Between the Spanish State and: the Federation of Evangelical Religious Entities of Spain (law n. 24), the Jewish Communities of Spain (law n. 25) and the Islamic Commission of Spain (law n. 26), in B.O.E. n. 272, 12 November 1992. 
the expulsion from our country of the religious minorities, possibly with more political than legal intention. And I think that it is proper for the Law to answer to social demands but not to anticipate them as it occurred with the 1992 Agreements.

In this way, the Spanish Agreement with the Islamic Commission was signed at a time when the cooperation with Islam still did not present problems in Spain. When they began, upon the notable increase of the Muslim presence in Spain as a consequence of immigration, the solutions that the Agreement offered were extremely vague and insufficient. With the 1992 Agreement, a representative organism for Islam was also established in our country, absolutely artificial, that is not representative of Islam in Spain and that is paralyzing the efficient application of the Agreement. This has occurred because, in order to sign the Agreement, the State requested the two existing federations of Islamic communities to unite in a single one (the Islamic Commission of Spain). The problem is that between the two Islamic federations there are important differences and rivalry. As they cannot agree between themselves, it is often difficult to apply the cooperation agreement signed with the State ${ }^{14}$.

Let me illustrate this with an example - for the civil validity of Islamic weddings in Spain, the consent of the parties shall be lent in the presence of two witnesses, who must be of age and one Islamic religious leader or Imam accredited by the Islamic Commission of Spain. We have been celebrating Islamic weddings with civil effects in spite of not having any religious leader or Imam accredited by the ICS. What would happen if the civil validity of these marriages were challenge? I don't know, it has not occurred till the moment. Another example: to be able to teach Islamic education in Spanish public schools the Islamic Commission of Spain must present to the Administration, so that it can approve it, a list of teachers of religion. However, the two Islamic Groups that constitute the Commission cannot agree on a list of teachers, and in some Spanish cities this Islamic education is not yet being imparted for this reason.

In any case, despite its deficiencies, the truth is that the Agreements with religious communities have provided tools for the accommodation of the Law.

\subsection{Mediation and arbitration as a way of accommodation of plurality in the field of Family Law: special reference to the Canadian case.}

In the area of Family law, a legal resource that is being used in our countries to adapt to the different cultural identities is the institution of mediation and arbitration. It makes it easier for the parties involved to resolve their conflicts in compliance with a law that is more close to them.

14 See I. JIMÉNEZ-AYBAR, El Islam en España. Aspectos institucionales de su estatuto jurídico, Navarra Gráfica Ediciones, Pamplona 2004, pp. 97 y 98. 
Furthermore, the alternative dispute resolution procedures contribute to lighten the court system load, to reduce the costs of the process, to avoid the publicity of subjects that parties want to keep private and to obtain a quick decision that prevents a greater exacerbation of the matrimonial conflict.

Mediation and arbitration also help to avoid the civil courts from the obligation to declare with reference to institutions with which they are not familiarized. In this way, there have even been cases in which the civil courts have interpreted religious Law. Allow me to cite a curious example from a California Court. The disagreement between the different experts called to testify before the Court, has forced the American Court to take part in the interpretation of the Islamic law when it shouldn't because it has neither the qualifications nor the competence to do it. The Court had to decide whether a Muslim woman loses her right to the dower or not when she is the one asking for a divorce. Particularly shocking is the following affirmation in which the American Court dares to refer to the wisdom of the Prophet. These are the words of the Court: "The court also finds that, if the wife initiates a termination of the relationship, she foregoes the dower, and the court so finds that, in this case, the wife initiated the termination of the marriage and common sense and wisdom of Mohamed would dictate that she forego the dower, unless the parties agree otherwise..."

However, despite the advantages, the submission of the conflicts of family Law to arbitration (and specifically religious arbitration) is not exempt from difficulties. Allow me to illustrate the problem with the example of Canada.

In Canada, the system in force in Ontario from 1991 to 2005, allowed arbitration to resolve certain family matters and, in fact, some religious communities had their own arbitration courts under the protection of this regulation. However, the creation of the Islamic Institute of Civil Justice at the end of 2003 that was created in order to allow Canadian Muslims to resolve their conflicts according to Islamic Law sparked an intense debate in the country. Among the group that rejected the Islamic arbitration were some sectors of the Canadian Muslim population, such as the Canadian Council of Muslim Women that played a fundamental role.

The reasons given to object were that there is not just one but several interpretations of the Islamic Law and that some of them are of patriarchal inspiration, harmful to women's equality.

The answer to this was that arbitration is voluntary and requires the consent of both parties. However, it was said that some women could feel obligated to attend these Islamic courts, in virtue of their religious convictions or under family and community pressure. This was one of the main reasons for the govern-

15 Dajani v. Dajani, Court of Appeal of California, Fourth Appellate District, Division Three, 1988. In a similar way, in Schwartzman v. Schwartzman (N.Y. Supreme Court, 1976) the Court ends by interpreting the Jewish law relative to the Mikvah as an essential element to become a Jew. 
ment to resolve the conflict in 2005 modifying the legislation in such a way that, after the reform, religious arbitration is no longer possible ${ }^{16}$.

Despite the unquestionable advantages of religious mediation and arbitration, it seems advisable to promote a gradual and prudent implementation, may be starting with mediation that allows judicial revision ${ }^{17}$.

\section{Conclusion}

To conclude, Western European legal systems are being claimed to accommodate a new social reality that is eminently plural. In my paper, I have pointed out some tools directed to this purpose.

I conclude by stressing the fact that allowing space for diversity does not mean, as some European people believe and fear, giving up our own values. Quite the opposite, accommodation comes from our own values: that is, from the respect for freedom and non-discrimination, founded on the dignity of the person.

16 Family Statute Law Amendment Act, introduced on November 15, 2005.

17 While the religious communities are not in a place to offer guarantees for an application of these means that is adequate in their idiosyncrasy but also compatible with the values and fundamental rights of our legislation. 